\title{
Traditional Market Transformation Into Digital Market (Indonesian Traditional Market Research Library)
}

\author{
Hari Purwanto $^{1^{*}}$, Heny Sidanti, ${ }^{2}$ Dian Citaningtyas Ari Kadi ${ }^{3}$ \\ 1,2,3 Economic and Business Faculty Universitas PGRI Madiun Indonesia \\ * Corresponding author: \\ Email: hari.purwanto@unipma.ac.id
}

\begin{abstract}
For many centuries traditional markets have become the economic strength of Indonesian society where trading business actors gather to carry out buying and selling transactions. Along with the development of the era, the advancement of information technology is developing very rapidly and changing many patterns of people live from various aspects of life as well as trade. In conventional trade, relying on traditional markets is considered inefficient considering the too long distribution channels of goods and the emergence of additional costs in trade, which causes a high cost economy. The shift of traditional markets to digital markets is an inevitable demand. This study discusses Digital Transformation in traditional markets and how the process should take place to provide some solutions to existing problems. The method used in this research is library research. The research locations are traditional Indonesian markets. Sources of data in this study were collected by collecting methods through literature, scientific publications, information from the internet. The data is induced and concludes the arguments that are made. The findings of this study are: The digital transformation of traditional markets to digital markets has not been fully carried out in Indonesia. Solution: Traditional market players are starting to open up to the online market. It is time for the government to build online infrastructure to move traditional markets to digital markets, although not completely so that marketing efficiency and convenience can increase overall welfare.
\end{abstract}

Keywords: Traditional Market, Online Market, Infrastructure, Government

\section{INTRODUCTION}

The Industrial Revolution 4.0 is a big leap in the main industrial sector of information and communication technology which is fully utilized to achieve enormous efficiency and effectiveness, thus giving birth to new forms of digital-based business. In the current Industrial Revolution 4.0, companies really need human resources who have new skills, which are still scarce. The Industrial Revolution 4.0 shifted several fields of work that would develop rapidly, on the other hand, some fields of work might decline or even disappear. The results of a survey conducted by the World Economic Forum stated that 4 types of technology that will dominate their role in 2018-2022, including artificial intelligence, big data analytics, high-speed mobile internet, and cloud technology. Of the four technologies, it will massively influence the system and development of the economy and business. Southeast Asia's Internet-based economy is achieving breakneck growth, a fundamental change in consumer behavior in a fast-growing digital-driven economy that has surged to $\$ 100$ billion in 2019, more than tripling its development over the past four years. It is estimated that by 2025 , the Internet economy will grow to $\$ 300$ billion.

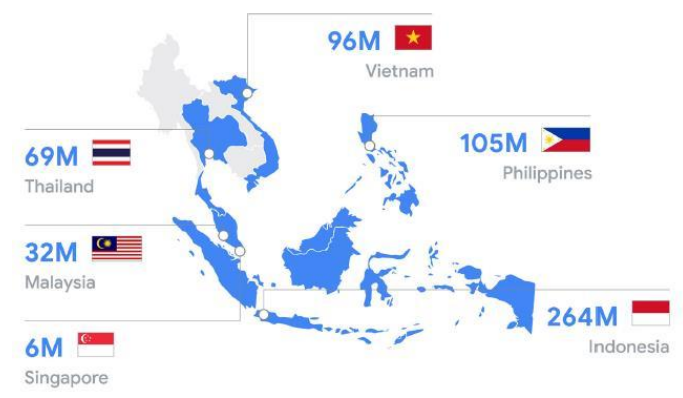

Source: [2]

$\underline{\text { http://ijstm.inarah.co.id }}$ 
The Internet economies in Southeast Asia, namely Thailand, Malaysia, the Philippines, and Singapore, are experiencing growth of between $20 \%$ and $30 \%$ per year, with no sign of slowing down. but the fastest growing growth rates are Indonesia and Vietnam, which lead to a growth rate of more than $40 \%$ per annum. It is estimated that Indonesia's Internet economy will reach $\$ 40$ billion by 2019, more than four times from 2015 at an average growth rate of $49 \%$ per annum. As the largest and fastest growing internet economy in Southeast Asia, Indonesia could cross the $\$ 130$ billion mark by 2025. [2] The market is a place for community activities to carry out buying and selling trades. The market consists of traditional markets as well as modern shops and shopping centers. Traditional markets as a community economic force that have existed for centuries have dominated trading activities in Indonesia. Traditional markets have an important role in the matter of advancing and driving the economic growth of the people. The important role of traditional markets is as an estuary for the products of the surrounding community, as well as a job opportunity for some people. [3] From the results of the survey by the Central Statistics Agency in 2018, the number of traditional markets in Indonesia amounted to 14,182 markets or $88.52 \%$ of all markets in Indonesia. Meanwhile, there are 1,131 modern shops or $7.06 \%$ of all markets in Indonesia.

Shopping centers amounted to 708 or $4.42 \%$. [4] This information shows that the existence of traditional markets still dominates market types in Indonesia. The domination of traditional markets explains that most of the buying and selling activities are still using traditional methods. Traditional markets that are managed conventionally that involve the circulation of goods and services through complicated and long distribution are prone to causing illegal levies and unexpected costs for the perpetrators. This is what makes traditional traders enjoy a little profit because the High Cost Economy that appears will be accumulated at the selling price. And one of the factors that are considered to be hindering economic growth in Indonesia, one of which is the High Cost Economy because it makes Indonesia lose if it has to compete in trade competition with other countries.[5] High Cost Economy is an economic process in a region or country. which entails higher costs due to higher tariffs or illegal levies that should not exist as a result of a 'culture of corruption. The impact of the high cost economy is that the expenditure of trading business actors is much higher which in the end is accumulated at the selling price.

As a result, the output price of the product is less competitive in the international market so that the local market itself has been flooded with imported products that are more efficient and thus cheaper.From the conditions above traditional markets which tend to be inefficient both in terms of trading mechanisms and distribution of goods which tend to require higher costs and with the growth of the internet economy that is developing very fast, it is time for traditional markets to revolutionize themselves to transform themselves into digital markets which are certainly far more efficient at linking sellers and buyers. From the background of the phenomena above it's important for this problem to be researched and taken for solutions for trade efficiency considering that technology supports this. From Agus' research, the factor that most influences the purchase of products via the internet is the efficiency factor compared to the effect of convenience and comfort factors.[6] With E-commerce, companies can expand their market place, get new customers, can provide services without a time limit to all their customers, as well as access to information that can be done quickly, and can establish good approaching, and relationships with customers.[7] The transformation of traditional markets to digital markets is a great opportunity for economic efficiency but on the other hand, there is also a negative impact, namely the loss of the livelihoods of some people who are engaged in traditional markets and fail to transform. [8] However, the transformation of traditional markets to digital is something that is not can be avoided.

\section{LITERATURE REIEW}

\subsection{Market}

The market is an economic institution where buyers and sellers meet, either directly or indirectly, to conduct trade transactions (Law No.7 of 2014). The market is a forum for community activities in conducting trade. The 
market consists of traditional markets as well as modern shops and shopping centers [4]The market is an institution as a means of practicing economic transactions that have existed since humans have recognized exchanges in fulfilling their daily needs. [9] An Online shop is a means or shop to offer goods and services via the internet so that online shop visitors can see goods in the store online.[10]

\subsection{Digital Transformation}

Digital transformation is an evolutionary process that relies on existing capabilities and digital technology to create or change business processes, operational processes and customer experiences to create new values.[11] The four driving factors for digital transformation are (1) regulatory changes ; (2) changing the competitive landscape; (3) changes to the digital form of the industry; (4) changes in consumer behavior and expectations [11]

\subsection{The Four Pillars of Digital Transformation}

Digital transformation is not to replace or refresh CRM or ERP and also not a step to restructure the company or start over, but it is an evolution of a business where it changes the business from conventional to digital-based, from offline to online and is carried out on a large or comprehensive scale. Four pillars are the focus of digital transformation change.[12]

\section{Empower your employees}

Increase collaboration, boost productivity and maximize mobility to attract and retain the best talent, as well as to mitigate future risks by providing freedom and space for employees. Implementing a digital culture for employees means maintaining a forward-thinking vision and empowering your team with the best, efficient tools to simplify collaboration and increase work productivity. Your employees are already using everyday productive tools like Word, Excel, Outlook, and PowerPoint but that's not enough. So the first step to take is to digitally empower them by adopting all these familiar tools into the cloud with Office 365 and adding apps like SharePoint, Teams, OneDrive, and Skype for real-time collaboration, mobility, and knowledge sharing.

\section{Engage your customers}

Build better and stronger interactions by leveraging data that represents a 360-degree view of customers. Empowering customers through direct involvement through technology is absolutely done by presenting an easy application. The main benefit of digital is the possibility to track, measure, and report every activity and action taken by a customer. For example, business intelligence is built into all Microsoft solutions, so we can visualize relevant data and KPIs on customizable dashboards and monitor the real-time performance of our digital business. The power of a holistic view of our business and our customers shows all the ways to optimize experiences to be more personalized and more profitable.

\section{Optimize your operations}

Optimizing operations to reshape customer relationships and service models by gathering data across multiple distributed endpoints, and drawing insights through sophisticated analytics that can be used to introduce and improve continuously and over time. SaaS (Software as a Service) and consumption-based models for modern infrastructure are now more conventional ways to buy technology. A perfect example is the realization of Dynamics 365, a powerful Microsoft SaaS that integrates CRM and ERP into one service to provide end-toend business functionality: Finance, Automation, Sales, Marketing, Project Services, Customer Service, Operations, and Field Services. These models and concepts will not only reduce the initial capital investment but will also increase the agility to change if and someday needed.

\section{Transform your service offerings}

Discover and redesign products, services, and business models using digital content to take advantage of better revenue opportunities. New competitors focused on new consumer behavior and expectations will change the game, services that use digital and technology to disrupt established business models. To emulate existing digital-first firms, businesses need to adapt their technology and business models and offerings as well, finding ways to differentiate them from the new products and services being developed. 


\subsection{Previous Research}

Ari Margiono's research found that there are two paths that companies may take to undergo digital transformation. The combination of the two paths is also possible. The Digital offensive transformation uses portfolio investment and M\&A tactics while digital defensive transformation relies on the organic growth of new capabilities in existing companies. The path chosen depends on several contingent factors such as the amount of resistance and inertia within the firm, the ambiguity of the causes, and the availability of financial resources funding the transformation.[13]Research conducted by Wail El Hilali, Abdellah El Manouar and Mohammed Abdou Janati Idrissi, who found that the customers, data, and driving innovation that companies must work on during digital transformation, have a significant impact on the company's efforts to achieve sustainability. However, in contrast to the existing literature, the authors find that competition does not play an important role in increasing corporate sustainability commitment [14]Jan Holmström's research found that the introduction of digital manufacturing is likely to result in a hybrid solution, combining conventional logistics, digital manufacturing, and user operations. Immediate benefits can be identified in the form of extended life cycles and increased parts availability in challenging locations. Also there are opportunities for equipment manufacturers and LSPs to adopt new roles, thereby supporting the efficiency and sustainable use of digital manufacturing.[15] Research from Annika Steiber found that common drivers of, and clear barriers to the transformation of the two companies, were identified. The innovation diffusion framework was found to work very well in identifying these factors. Research limitations / implications - The implication is that researchers can better analyze / explain the digital transformation of companies, and business managers can plan or improve their company's transformation with better processes [16]Research from Dilek Cetindamar Kozanoglu found that his research draws on ability theory, and develops a new framework for the conceptualization of employee digital literacy as an organizational capability.

We do this by differentiating digital literacy at the individual and organizational levels, and by assessing digital literacy through Information / Cognitive and Social Practice / Articulation skills.Research from Feng Li found that Research found that at least three new approaches emerged in leading organizations, namely (1) innovating by experimenting, (2) radical transformation through sequential incremental change, and (3) dynamic sustainable profit through a portfolio of temporary benefits. growing. [17]Research conducted by Stefan Wengler found that in the implementation of digital transformation in the field of sales there was a loss of productivity gains due to limited knowledge of the main factors for successful digital transformation and a lack of understanding of digital transformation as a developing process [18]Christoph F. Breidbach's research found that determining the complexity of the digital financial service system (micro level), orchestrating the value of co-creation with Fintech (meso level), and developing elastic infrastructure, models, and markets (macro level). So it is very important the role of information and communication technology in services in general, and digital transformation in financial services [19]Research by Anjar Priyono found that SMEs carry out different levels of digital transformation, which can be summarized into three types based on company contextual factors. First, SMEs with a high level of digital maturity that respond to challenges by accelerating the transition to digital companies; second, SMEs have liquidity problems with low digital maturity levels that decide to focus solely on digitizing the sales function; and third, SMEs that have very limited digital literacy but are supported by high social capital [20]

\section{METHODS}

The research design used in this research is descriptive qualitative research with Desk / Library Research. In the study of qualitative, inductive, methodological designs that are evolving, the investigator can define some terms at the outset although it may advance a tentative definition.[21] The research location is traditional Indonesian markets. Sources of data in this study were collected by collecting methods through literature, scientific publications, internet information. The data is induced and draws conclusions on the 
arguments that are made. Researchers collect various forms of data, such as interviews, observations, documents, and audiovisual information rather than relying on a single data source. Then the researcher reviews all the data, understands it, and organizes it into categories or themes that cover all data sources. Qualitative researchers construct their patterns, categories, and themes from the ground up by organizing data into increasingly abstract units of information. This inductive process describes working back and forth between themes and databases until the researcher has established a comprehensive set of themes [21]. The role of the researcher is only as an observer and participant, meaning that the researcher is not directly involved in solving problems in the research object. Data analysis consist of: (1) data collection (2) data display (3) data reduction and (4) conclusions. [22]

\section{RESEARCH FINDINGS}

Based on observations, interviews, and collection of information based on internet libraries and mass media as well as processing research data, some of the findings can be described as follows:

4.1 There has been no formal government effort to build digital market infrastructure as a substitute or complement to traditional markets

It cannot be denied that the need for an online market is getting stronger considering the support of increasingly sophisticated information technology facilities. However, the public has yet to feel the effort to respond more quickly to these changes with the government's policy to build a digital market to complement the main physical market, the traditional market. Infrastructure development is focused on the physical, while times have changed, the demands of the online Market Place are getting bigger and it is only the private sector that provides these services. It is time for the government to provide infrastructure facilities in the form of an official market place to support traditional markets, considering the number of traditional markets which amounted to $88.52 \%$ dominating trading activities as well as the demands of conditions during the Covid 19 pandemic where social restrictions greatly hampered the trade transaction process.

4.2 There has been no attempt to massively transform traditional markets into online markets by the government

Although the development of information technology has spread to all elements of life, efforts to develop traditional markets into online markets have not been done much by the government. Currently, the only effort to transform the digital traditional market is Cikurubuk Market. Since transforming into an online market, Cikurubuk Online Market has reached sales of up to 19,000 products in November 2020. However, this is only the initial step of the local government which is based on a decline in sales of up to $50 \%$ due to the Covid 19 pandemic, which encourages market managers to change to an online system. However, there is no policy has been done by the Indonesian government. [23]

\subsection{Policy Payment systems via E-Money and fintech have not been touched}

One of the supporters of online trading is the support for payment instrument infrastructure. The government and the State as institutions that are responsible for controlling the trading and payment system should respond earlier to the need for electronic money and information technology in the financial sector (fintech) in order to spur the growth of more efficient trading through online market.

\subsection{Service delivery and distribution of goods by the government is still minimal}

Goods delivery and distribution services are needed to support online market transactions. The rise and development of online commerce is not supported by the readiness of the government to provide official, safe and cheap shipping services. These services are widely used by the private sector so that they often pose a big risk to the security and guarantee of the safety of goods. 


\section{DISCUSSION}

From the findings above, there is a need for further discussion to find solutions to the importance of the government as a policy holder to facilitate digital transformation in traditional markets to online markets. Things that can be a solution include:

5.1 The government builds a formal online market infrastructure as a substitute or complement to traditional markets in the form of a marketplace.

Online commerce (e-commerce) in Indonesia has had extraordinary developments where transactions have continued to increase over the past five years. The marketplace is one of the biggest players in Indonesia's e-commerce business today. From the data released by Katadata.com, in 2014 the value of Indonesia's online trade transactions was only 25.1 trillion rupiah, but in 2016 it had reached 108.4 trillion rupiah. It is estimated that in 2018 the transaction value will increase to 144.1 trillion rupiah. The Marketplace is an intermediary between online sellers and buyers. Marketplace sites act as a third party in online transactions by providing a place to sell and secure payment facilities. You could say that the marketplace is an online department store. Unfortunately, the Marketplace in Indonesia is mostly controlled and controlled by the private sector. So considering that the movement of the online shop cannot be avoided in accordance with the demands of the times and technology, as well as protecting conventional traders who have limitations in competition, the government whose job is to protect all public interests must be able to create and control a marketplace which will later serve as a supporter of traditional markets. This is in line with Dilek's research which states that abilities and develops a new framework for the conceptualization of employee digital literacy as organizational capabilities.[24]

\subsection{Efforts to transform traditional markets into online markets by the government as a whole}

This transformation is done by preparing the community and economic actors, especially traditional market traders, to be trained and prepared through a clear work program. The government must be offensive in picking up the ball so that opportunities for public welfare are quickly realized with cheaper trade efficiency according to research from Margiono [13]

Table 1. Four Pillars

\begin{tabular}{|c|c|c|c|}
\hline $\begin{array}{l}\text { FOUR } \\
\text { PILLARS }\end{array}$ & $\begin{array}{l}\text { TRADITIONAL } \\
\text { MARKET TRADERS }\end{array}$ & $\begin{array}{l}\text { GOVERNMENT } \\
\text { ROLE }\end{array}$ & $\begin{array}{l}\text { EXPECTED DIGITAL } \\
\text { MARKET }\end{array}$ \\
\hline $\begin{array}{l}\text { 1. Empower } \\
\text { Your } \\
\text { Employees }\end{array}$ & $\begin{array}{l}\text { Prepare market traders to } \\
\text { be able to use technology, } \\
\text { online transactions, } \\
\text { payment systems and } \\
\text { delivery systems. }\end{array}$ & $\begin{array}{l}\text { Registering all stalls and } \\
\text { providing intensive } \\
\text { training to the } \\
\text { community, especially } \\
\text { traditional market traders, } \\
\text { involving technology } \\
\text { experts, the trade } \\
\text { department, the Ministry } \\
\text { of Communication and } \\
\text { Information, banking and } \\
\text { related parties. }\end{array}$ & $\begin{array}{l}\text { The digital market } \\
\text { (Marketplace) } \\
\text { operate to support } \\
\text { traditional markets owned } \\
\text { by traders so that traders } \\
\text { have both offline and } \\
\text { online stalls with the same } \\
\text { market name. }\end{array}$ \\
\hline $\begin{array}{l}2 . \\
\text { Engage your } \\
\text { customers }\end{array}$ & $\begin{array}{l}\text { Preparing buyers for } \\
\text { mastery of technology, } \\
\text { online transactions, } \\
\text { ordering, payment, and } \\
\text { receipt of goods and } \\
\text { complaints. }\end{array}$ & $\begin{array}{l}\text { Providing socialization of } \\
\text { the existence of } \\
\text { traditional market-based } \\
\text { online markets to existing } \\
\text { traditional market } \\
\text { customers in order to be } \\
\text { able to take advantage of } \\
\text { both offline and online by } \\
\text { involving technology } \\
\text { experts, the trade } \\
\text { department, the Minister } \\
\text { of Communication and }\end{array}$ & $\begin{array}{l}\text { The formation of } \\
\text { consumers who are able } \\
\text { to take advantage of } \\
\text { online and offline markets } \\
\text { in the same market name } \\
\text { and in the same area. }\end{array}$ \\
\hline
\end{tabular}


Information, banking and related parties.

3. Optimize your operations product
The buying and selling operational system must be developed for online marketing where the stock of goods and displays must be reduced and prioritizes the availability and speed of service. Operates 24 hours without time limit and serves a very large marketing area.

Designing products to be easy in delivery and safe from damage. Efficient space and weight and the risk of being damaged is a priority.
The government comprehensively supports online marketing operations by optimizing the ease of payment services and ensuring the security of trade operations.
It is hoped that the online offline buying and selling process will run simultaneously to support each other without any operational problems.
The government The distribution of goods facilitates limited locally and widely is well shipping services in the accommodated market area where it stands and is widely available and guarantees security

5.3 Policy on the use of payment systems through E-Money and fintech information technology to support the online market

Many countries have implemented the use of E-Money and it turns out that its use is very successful where with electronic money online shop activities will be greatly helped and facilitated. The government authorities that control the payment system and financial institutions should provide more facilities and attention to the use of e-money in Indonesia considering that the need for online transactions is growing rapidly from time to time. E-money support for the development of traditional markets that are driven to be transformed online will be very much needed considering a large number of traditional markets in Indonesia. To protect the public interest, e-money facilities and ease of use services are mandatory for the government to provide because of the movement of information technology that requires it to exist and be available so that the domestic economy can compete with other countries. Besides the existence of information systems and technology in a payment system that supports integrated fintech needs to be pursued. Development of infrastructure, models, and elastic markets and the very important role of information and communication technology in services.[19] AFTECH which has been officially appointed by the Financial Services Authority (OJK) as the Association for Digital Financial Innovation Organizers based on POJK No.13 / 2018, where AFTECH has more than 350 members, consisting of 359 fintech companies, 24 financial institutions, as well as 13 research partners, and six technology partners, its role needs to be further developed to support the transformation of traditional markets to digital markets as a whole by providing facilities and supporting infrastructure. [25]

5.4 The government must develop and provide good and safe services for the delivery and distribution of goods.

Considering digital transformation in traditional markets will be carried out comprehensively, the need for following an online shop, namely safe shipping services, is absolutely necessary. The most favorite shipping services used in Indonesia include JNE Express, Pos Indonesia, Tiki, J\&T Express, Ninja Express, Wahana, Si Cepat Express, Deliveree, Grab Express, Go send and Go Box. [26] Shipping services are controlled by the private sector. If the transformation of traditional markets to digital markets is carried out, the government must take over the role of the private sector which has been dominating this role considering that online shops are increasingly widespread today. If the application of the online shop is expected to touch all traditional markets, inevitably the role of the government will be very necessary considering that there are so many people that must 
be served and this is not sufficient to leave it to the private sector for the sustainability of its operations. This is in line with the research of Wail El Hilali, Abdellah El Manouar, and Mohammed Abdou Janati Idrissi who found that customers, data, and driving innovations that companies must work on during digital transformation have a significant impact on the company's efforts to achieve sustainability [14]

\section{SUMMARY AND SUGGESTION}

\subsection{Conclusion}

Based on the research findings and the above discussion descriptions, the following conclusions can be drawn. Digital transformation in the economic sector, especially trade, is not an option but a necessity because considering the demands of the times and technology, the government as an asset manager and protector of the people's economy must immediately take steps to transform traditional markets online, even though it is not completely. With all the weaknesses and strengths of the online market, it gives hope that the efficiency and effectiveness of people's trade are easier and cheaper to avoid the High Cost Economy. Things that can be done to make this happen to include:

1. The government builds a formal online market infrastructure as a substitute or complement to traditional markets in the form of a marketplace

2. Attempts to transform traditional markets into online markets by the government as a whole

3. Policy on the use of payment systems through E-Money and infrastructure for fintech to support the online shop

4. The government must build and provide good and safe goods delivery and distribution services to support the digital market

\subsection{Suggestions}

Regarding these conditions, to realize digital transformation in traditional markets in order to prosper the people through an efficient trading system, the role of the government is committed to realizing this through traditional market-oriented policies that are supported by modern systems. However, it should be remembered that knowledge of the main factors that make digital transformation successful and understanding of digital transformation itself as a process that is constantly evolving needs to be understood by business actors, namely the community of traditional market players who will be transformed so as not to experience a decrease in sales productivity. [18] Excessive surrender of the digital-based economy to the private sector is not the right policy, so in order to protect the economic interests of society at large, the government must take over that role.

\section{REFERENCES}

[1] T. Hidayat, "INDUSTRY 4.0,” 2019. [Online]. Available: https://www.unida.ac.id/teknologi/artikel/trendteknologi-revolusi-industri-40.html\#.

[2] GOOGLE TEMASEK BAIN \& COMPANY, “e-Conomy SEA 2019,” pp. 1-65, 2019.

[3] I. Brata, "Pasar Tradisional Di Tengah Arus Budaya Global," J. Ilmu Manaj. Mahasaraswati, vol. 6, no. 1, p. 102449, 2016.

[4] Badan Pusat Statistik, "Badan Pusat Statistik," pp. 335-58, 2017.

[5] A. B. U. Kosim, "Ekonomi pembangunan ekonomi biaya tinggi, investasi dan pertumbuhan ekonomi," J. Ekon. dan Pembang. Indones., vol. 7, no. 2, pp. 54-61, 2009.

[6] A. W. WIDODO, "Analisis Pengaruh Kemudahan, Kenyamanan Dan Efisiensi Terhadap Frekwensi Pembelian Produk Melalui Internet," 2019.

[7] S. Rosyad, "EFEKTIFITAS DAN EFISIENSI PENERAPAN E-COMMERCE PADA PT. WAHANA SURYA PLASTIK," Persepsi Masy. Terhadap Perawatan Ortod. Yang Dilakukan Oleh Pihak Non Prof., vol. 53, no. 9, pp. 1689-1699, 2013.

[8] Liviana Dwi Putri danYuspina Kurbayanti, “Transformasi Pasar Tradisional Menjadi Pasar Online,” 2021. [Online]. Available: https://www.solopos.com/transformasi-pasar-tradisional-menjadi-pasar-online-1102122.

[9] P. Karl, The Great Transformation: The Political and Social Origins of Our Time. Yogyakarta: Pustaka Pelajar., 
2003.

[10] C. A. Sari, "Perilaku Berbelanja Online Di Kalangan Mahasiswi Antropologi Universitas Airlangga," J. Antro Unair, vol. 4, no. 2, pp. 205-216, 2015.

[11] K. Hadiono and R. C. NoorSanti, "Menyongsong Transformasi Digital," Sendiu 2020, no. July, pp. 978-979, 2020.

[12] H. F. Binner, Digital business models = success, vol. 25, no. 1. 2020.

[13] A. Margiono, "Digital transformation: setting the pace," J. Bus. Strategy, no. May, 2020.

[14] W. El Hilali, A. El Manouar, and M. A. Janati Idrissi, "Reaching sustainability during a digital transformation: a PLS approach,” Int. J. Innov. Sci., no. 2018, 2020.

[15] J. Holmström and J. Partanen, "Digital manufacturing-driven transformations of service supply chains for complex products," Supply Chain Manag., vol. 19, no. 4, pp. 421-430, 2014.

[16] A. Steiber, S. Alänge, S. Ghosh, and D. Goncalves, "Digital transformation of industrial firms: an innovation diffusion perspective," Eur. J. Innov. Manag., 2020.

[17] F. Li, "Leading digital transformation: three emerging approaches for managing the transition," Int. J. Oper. Prod. Manag., vol. 40, no. 6, pp. 809-817, 2020.

[18] S. Wengler, G. Hildmann, and U. Vossebein, "Digital transformation in sales as an evolving process," J. Bus. Ind. Mark., vol. ahead-of-p, no. ahead-of-print, 2021.

[19] C. F. Breidbach, B. W. Keating, and C. Lim, "Fintech: research directions to explore the digital transformation of financial service systems," J. Serv. Theory Pract., vol. 30, no. 1, pp. 79-102, 2019.

[20] A. Priyono, A. Moin, and V. N. A. O. Putri, "Identifying digital transformation paths in the business model of smes during the covid-19 pandemic,” J. Open Innov. Technol. Mark. Complex., vol. 6, no. 4, pp. 1-22, 2020.

[21] J. W. Creswell, RESEARCH DESIGN, 4th ed. United Kingdom: SAGE Publications Asia-Pacific Pte. Ltd., 2014.

[22] A. M. H. Miles, Mathew B., An Expanded Sourcebook: Qualitative Data Analysis. Sage Publications, 1994.

[23] K. Runiasari, “Transformasi pasar tradisional menjadi pasar online,” 2020. [Online]. Available: https://www.alinea.id/infografis/transformasi-pasar-tradisional-menjadi-pasar-online-b1ZWL9y0r.

[24] D. Cetindamar Kozanoglu and B. Abedin, "Understanding the role of employees in digital transformation: conceptualization of digital literacy of employees as a multi-dimensional organizational affordance," J. Enterp. Inf. Manag., 2020.

[25] Fintech Indonesia, "Fintech Indonesia," 2020. [Online]. Available: https://fintech.id/id.

[26] Magoo Store, “10 Jasa Pengiriman Barang Favorit Bisnis Online.” [Online]. Available: https://www.magoostoreid.com/post/10-jasa-pengiriman-barang-favorit-bisnis-online. 